\title{
PENGARUH MOTIVASI BERPRESTASI TERHADAP KINERJA GURU DI SMK TUNAS PEMUDA
}

\author{
Titik Haryanti \\ Dosen Politeknik Tunas Pemuda \\ Email: titikharyanti19@gmail.com
}

\begin{abstract}
Abstrak
Penelitian ini bertujuan untuk mengetahui pengaruh motivasi berprestasi terhadap kinerja guru di SMK Tunas Pemuda. Peneliti menggunakan metode penelitian survei. Populasi dalam penelitian ini adalah seluruh guru SMK Tunas Pemuda yang berjumlah 40 guru. Sampel dalam penelitian ini berjumlah 30 yang diambil dengan random sampling atau acak sederhana. Sumber data penelitian yaitu guru-guru SMK Tunas Pemuda. Teknik pengumpulan data yaitu angket dengan skala likert. Teknik analisis data yang digunakan adalah teknik analisis korelasi product moment, regresi sederhana, dan uji t untuk menguji hipotesis penelitian. Hasil penelitian sebagai berikut: 1 . Hasil pengujian regresi menghasilkan persamaan regresi $\hat{Y}$ $=13,071+0,677 \mathrm{x}$ yang artinya setiap kenaikan satu unit variabel motivasi berprestasi akan meningkatkan variabel kinerja guru sebesar 0,677 dan apabila tidak ada variabel motivasi berprestasi maka kinerja guru akan tetap sebesar 13,071. 2. Hasil pengujian korelasi sederhana menghasilkan nilai 0,743 yang artinya hubungan antara variabel motivasi berprestasi dengan variabel kinerja guru sebesar 0,743 yang artinya hubungan tersebut positif dan kuat. Hubungan yang positif tersebut mengartikan bahwa apabila motivasi berprestasi guru naik maka kinerja guru akan naik dan apabila motivasi berprestasi guru turun maka kinerja guru akan turun. Koefisien determinan menghasilkan nilai 55,2 \% yang artinya motivasi berprestasi menjelaskan kinerja guru sebesar 55,2 \% dan sisanya sebesar 44,8 \% dari variabel lain. 3 . Hasil pengujian menjelaskan bahwa t hitung sebesar 5,871 > t tabel sebesar 2,048 maka $\mathrm{H}_{0}$ ditolak yang artinya artinya terdapat pengaruh yang signifikan variabel motivasi berprestasi terhadap variabel kinerja guru di SMK Tunas Pemuda.
\end{abstract}

Kata Kunci: Motivasi berprestasi, kinerja guru

\section{PENDAHULUAN}

Kinerja guru merupakan faktor yang dapat meningkatkan kemampuan siswa menjadi baik. Oleh karena itu, kinerja guru harus selalu ditingkatkan dengan programprogram yang dapat meningkatkan kinerja guru, seperti meningkatkan motivasi berprestasi guru.

Destiyani Gati (2012), menyatakan bahwa, tingkat motivasi berprestasi guru Sekolah Dasar Negeri di kecamatan Pringsurat sebesar 77\% dalam kategori sedang; 2) Tingkat kinerja guru di Sekolah Dasar Negeri di kecamatan Pringsurat sebesar 85\% dalam kategori tinggi; 3) Motivasi berprestasi guru berpengaruh positif dan signifikan terhadap kinerja guru Sekolah Dasar Negeri di kecamatan Pringsurat ditunjukkan dengan koefisien korelasi sebesar 0,24, koefisien determinasi 0,06, F hitung sebesar 8,47, sumbangan efektifnya sebesar 6\%.

Berdasarkan hasil penelitian tersebut menyatakan bahwa motivasi berprestasi berpengaruh terhadap kinerja guru. Oleh karena itu, guru harus memiliki motivasi 
berprestasi yang dapat digunakan untuk meningkatkan kinerjanya dalam mengajar di kelas.

Permasalahannya adalah masih banyak guru yang memililiki kinerja yang rendah sehingga mempengaruhi kualitas siswa yang diajarnya. Masih ada guru yang tidak membuat rencana pelaksanaan pembelajaran, guru yang datang terlambat, guru yang masih tidak kreatif dalam mengajar, guru yang tidak mau menggunakan media pembelajaran, dan lain-lain.

Kondisi tersebut yang membuat guru memiliki kinerja yang rendah. Hal ino disebabkan guru tidak memiliki motivasi berprestasi yang tinggi sehingga guru menjadi malas dalam bekerja dan tidak memiliki target dalam bekerja. Guru bekerja tidak memiliki perencanaan dan target yang jelas sehingga guru dalam mengajar yang terpenting adalah masuk kelas dan materi selesai.

Guru yang memiliki motivasi berprestasi yang tinggi akan selalu bekerja dengan keinginan untuk dapat berprestasi sehingga guru dalam bekerja selalu berdasarkan perencanaan yang matang dan tepat. Guru yang bekerja dengan motivasi berprestasi yang tinggi akan selalu meningkatkan kemampuanya agar supaya hasil kerjanya berkualitas.

Berdasarkan permasalahan tersebut, peneliti tertarik mengadakan penelitian dengan judul, Pengaruh Motivasi Berprestasi Terhadap Kinerja Guru Di Smk Tunas Pemuda.

\section{TINJAUN PUSTAKA}

\section{Pengertian Kinerja Guru}

Kinerja berasal dari pengertian performance. Ada pula yang memberikan pengertian performance sebagai hasil kerja atau prestasi kerja. Namun sebenarnya kinerja mempunyai makna yang lebih luas, bukan hanya hasil kerja, tetapi termasuk bagaimana proses pekerjaan berlangsung (Wibowo, 2016: 7). Indikator yang mempengaruhi kinerja karyawan diantaranya yaitu 1) kemampuan menyelesaikan pekerjaan, 2) kemampuan mengerjakan pekerjaan lain, 3) tanggung jawab, 4) ketelitian dalam bekerja, 5) tingkat kehadiran dan ketepatan waktu 6) kemampuan bekerja sama, dan 7) kemampuan berkomunikasi.

Menurut Mangkunegara, 2001: 67 kinerja dapat didefinisikan sebagai hasil kerja secara kualitas dan kuantitas yang dapat dicapai oleh seseorang pegawai dalam melaksanakan tugas sesuai dengan tanggungjawab yang diberikan kepadanya. (Cascio, 
1995: 275) mengatakan bahwa kinerja merupakan prestasi karyawan dari tugas-tuganya yang telah ditetapkan. (Soeprihantono, 1988 :7); mengatakan bahwa kinerja merupakan hasil pekerjaan seorang karyawan selama pereode tertentu dibandingkan dengan berbagai kemungkinan, misalnya standard, target/sasran/criteria yang telah ditentukan terlebih dahulu dan telah disepakati bersama.

Menurut Harbani Pasolong (2010:186), faktor-faktor yang mempengaruhi kinerja pegawai adalah sebagai berikut : a) Kemampuan, yaitu kemampuan dalam suatu bidang yang dipengaruhi oleh bakat, intelegensi (kecerdasan) yang mencukupi dan minat. b) Kemauan, yaitu kesediaan untuk mengeluarkan tingkat upaya yang tinggi untuk tujuan organisasi. c) Energi, yaitu sumber kekuatan dari dalam diri seseorang. Dengan adanya energi, seseorang mampu merespon dan bereaksi terhadap apapun yang dibutuhkan, tanpa berpikir panjang atau perhatian secara sadar sehingga ketajaman mental serta konsentrasi dalam mengelola pekerjaan menjadi lebih tinggi. d) Teknologi, yaitu penerapan pengetahuan yang ada untuk mepermudah dalam melakukan pekerjaan. e) Kompensasi, yaitu sesuatu yang diterima oleh pegawai sebagai balas jasa atas kinerja dan bermanfaat baginya. f) Kejelasan tujuan, yaitu tujuan yang harus dicapai oleh pegawai. Tujuan ini harus jelas agar pekerjaan yang dilakukan oleh pegawai dapat terarah dan berjalan lebih efektif dan efisien. g) Keamanan, yaitu kebutuhan manusia yang fundamental, karena pada umumnya seseorang yang merasa aman dalam melakukan pekerjaannya, akan berpengaruh kepada kinerjanya.

Menurut T.R. Michel dalam Rizky (2001:15) indikator kinerja meliputi : a) Kualitas pelayanan (Quality of work), yaitu kualitas pekerjaan yang dihasilkan dapat memuaskan bagi penggunanya atau tidak, sehingga hal ini dijadikan sebagai standar kerja. b) Komunikasi (Communication), yaitu kemampuan pegawai dalam berkomunikasi dengan baik kepada konsumen. c) Kecepatan (Promptness), yaitu kecepatan bekerja yang diukur oleh tingkat waktu, sehingga pegawai dituntut untuk bekerja cepat dalam mencapai kepuasan dan peningkatan kerja. d) Kemampuan (Capability), yaitu kemampuan dalam melakukan pekerjaan semaksimal mungkin. e) Inisiatif (Intiative), yaitu setiap pegawai mampu menyelesaikan masalah pekerjaannya sendiri agar tidak terjadi kemandulan dalam pekerjaan.

Berdasarkan kutipan-kutipan di atas, peneliti menyimpulkan bahwa kinerja guru adalah hasil kerja guru yang memiliki kulitas dan produktivitas yang dinilai dengan 
instrumen yang berlaku di Sekolah dengan indikator kualitas pelayanan (Quality of work), yaitu kualitas pekerjaan yang dihasilkan dapat memuaskan bagi penggunanya atau tidak, sehingga hal ini dijadikan sebagai standar kerja. b) Komunikasi (Communication), yaitu kemampuan pegawai dalam berkomunikasi dengan baik kepada konsumen. c) Kecepatan (Promptness), yaitu kecepatan bekerja yang diukur oleh tingkat waktu, sehingga pegawai dituntut untuk bekerja cepat dalam mencapai kepuasan dan peningkatan kerja. d) Kemampuan (Capability), yaitu kemampuan dalam melakukan pekerjaan semaksimal mungkin. e) Inisiatif (Intiative), yaitu setiap pegawai mampu menyelesaikan masalah pekerjaannya sendiri agar tidak terjadi kemandulan dalam pekerjaan.

\section{Pengertian Motivasi Berprestasi}

Motivasi asalnya dari kata motif, dalam bahasa Inggris adalah motive atau motion, lalu motivation, yang berarti gerakan atau sesuatu yang bergerak.Artinya sesuatu yang menggerakan terjadinya gerakan tindakan, atau disebut dengan niat.

Menurut Handoko, ( 1999: 252), menyatakan bahwa, '’Banyak istilah yang digunakan untuk menyebut motivasi (motivation) atau motif, antara lain kebutuhan (need), desakan (urge),keinginan(wish), dan dorongan (drive)', Sedangkan menurut Hamalik, (2003:158), mendefinisikan, Motivasi adalah perubahan energi dalam diri (pribadi) seseorang yang ditandai dengan timbulnya perasaan dan reaksi untuk mencapai tujuan'’.Selanjutnya Sutikno, (2007: 137), mengartikan '’Motivasi adalah sesuatu yang mendorong seseorang untuk bergerak, baik disadari maupun tidak disadari.

Menurut Mc Clelland (1987: 40) pengertian motivasi berprestasi didefinisikan sebagai usaha mencapai sukses atau berhasil dalam kompetisi dengan suatu ukuran keunggulan yang dapat berupa prestasi orang lain maupun prestasi sendiri. Lindgren (1976: 67) mengemukakan hal senada bahwa motivasi berprestasi sebagai suatu dorongan yang ada pada seseorang sehubungan dengan prestasi, yaitu menguasai, memanipulasi serat mengatur lingungan sosial maupun fisik, mengatasi segala rintangan dan memelihara kualitas kerja yang tinggi, bersaing melalui usaha-usaha untuk melebihi hasil kerja yang lampau, serta mengungguli hasil kerja yang lain.

Senada dengan pendapat di atas, Santrork (2003: 103) menjelaskan bahwa motivasi berprestasi merupakan keinginan untuk menyelesaikan sesuatu untuk mencapai suatu standar kesuksesan, dan untuk melakukan suatu usaha dengan tujuan untuk 
mencapai kesuksesan. Gagne dan Barliner (1975: 77) menambahkan bahwa motivasi berprestasi adalah cara seseorang untuk berusaha dengan baik untuk prestasinya.

Menurut Heckhausen (1967: 54) motif berprestasi diartikan sebagai usaha untuk meningkatkan atau melakukan kecakapan pribadi setinggi mungkin dalam segala aktivitas dan suatu ukuran keunggulan tersebut digunakan sebagai pembanding, meskipun dalam usaha melakukan aktivitas tersebut ada dua kemungkinan yakni gagal atau berhasil. Selanjutnya ia menjelaskan bahwa motivasi berprestasi merupakan motif yang mendorong individu untuk mencapai sukses dan bertujuan untuk berhasil dalam kompetisi dengan beberapa ukuran keunggulan (standard of excellence). Ukuran keunggulan digunakan untuk standar keunggulan prestasi dicapai sendiri sebelumnya dan layak seperti dalam suatu kompetisi.

Berdasarkan teori-teori tersebut di atas, dapat disimpulkan bahwa motivasi berprestasi adalah dorongan dari luar maupun dalam diri seseorang untuk bekerja dengan baik dan menghasilkan kinerja yang berkualitas dengan usaha-usaha profesional dan terukur dan bersaing dengan positif serta ingin selalu berprestasi dengan indikator bekerja karena ingin hasil yang baik dan berkualitas, bersaing dengan positif, dan selalu ingin berprestasi.

\section{METODE}

Peneliti menggunakan metode penelitian survei. Populasi dalam penelitian ini adalah seluruh guru SMK Tunas Pemuda yang berjumlah 40 guru. Sampel dalam penelitian ini berjumlah 30 yang diambil dengan random sampling atau acak sederhana. Sumber data penelitian yaitu guru-guru SMK Tunas Pemuda. Teknik pengumpulan data yaitu angket dengan skala likert. Teknik analisis data yang digunakan adalah teknik analisis korelasi product moment, regresi sederhana, dan uji t untuk menguji hipotesis penelitian. 


\section{HASIL DAN PEMBAHASAN}

\section{Uji Regresi Sederhana}

Tabel 1. Hasil Pengujian Regresi Sederhana

Coefficients $^{\mathrm{a}}$

\begin{tabular}{|c|c|c|c|c|c|c|}
\hline \multirow{2}{*}{\multicolumn{2}{|c|}{ Model }} & \multicolumn{2}{|c|}{ Unstandardized Coefficients } & \multirow{2}{*}{$\begin{array}{c}\text { Standardized } \\
\text { Coefficients }\end{array}$} & \multirow[b]{2}{*}{$\mathrm{t}$} & \multirow[b]{2}{*}{ Sig. } \\
\hline & & B & Std. Error & & & \\
\hline 1 & (Constant) & 13.071 & 5.065 & & 2.581 & .015 \\
\hline & $\mathrm{X}$ & .677 & .115 & .743 & 5.871 & .000 \\
\hline
\end{tabular}

a. Dependent Variable: Y

Berdasarkan tabel di atas, hasil pengujian regresi menghasilkan persamaan regresi $\hat{Y}=13,071+0,677 x$ yang artinya setiap kenaikan satu unit variabel motivasi berprestasi akan meningkatkan variabel kinerja guru sebesar 0,677 dan apabila tidak ada variabel motivasi berprestasi maka kinerja guru akan tetap sebesar 13,071.

\section{Uji Korelasi Sederhana}

Tabel 2. Hasil Pengujian Korelasi Sederhana

\begin{tabular}{|l|r|r|r|r|}
\hline & & & \\
\hline Model & $\mathrm{R}$ & $\mathrm{R}$ Square & Adjusted R Square & $\begin{array}{c}\text { Std. Error of the } \\
\text { Estimate }\end{array}$ \\
\hline 1 & $.743^{\mathrm{a}}$ & .552 & .536 & 2.361 \\
\hline
\end{tabular}

Berdasarkan tabel di atas, hasil pengujian korelasi sederhana menghasilkan nilai 0,743 yang artinya hubungan antara variabel motivasi berprestasi dengan variabel kinerja guru sebesar 0,743 yang artinya hubungan tersebut positif dan kuat. Hubungan yang positif tersebut mengartikan bahwa apabila motivasi berprestasi guru naik maka kinerja guru akan naik dan apabila motivasi berprestasi guru turun maka kinerja guru akan turun. Koefisien determinan menghasilkan nilai 55,2 \% yang artinya motivasi berprestasi menjelaskan kinerja guru sebesar 55,2 \% dan sisanya sebesar 44,8 \% dari variabel lain. 


\section{Uji Hipotesis Penelitian (Uji t)}

Tabel 3. Hasil Pengujian Hipotesis Penelitian

Coefficients $^{\mathrm{a}}$

\begin{tabular}{|c|c|c|c|c|c|c|}
\hline \multirow{2}{*}{\multicolumn{2}{|c|}{ Model }} & \multicolumn{2}{|c|}{ Unstandardized Coefficients } & \multirow{2}{*}{$\begin{array}{c}\text { Standardized } \\
\text { Coefficients }\end{array}$} & \multirow[b]{2}{*}{$\mathrm{t}$} & \multirow[b]{2}{*}{ Sig. } \\
\hline & & B & Std. Error & & & \\
\hline 1 & (Constant) & 13.071 & 5.065 & & 2.581 & .015 \\
\hline & $\mathrm{X}$ & .677 & .115 & .743 & 5.871 & .000 \\
\hline
\end{tabular}

Berdasarkan tabel di atas, hasil pengujian hipotesis penelitian menghasilkan nilai t hitung sebesar 5,871 dan t tabel dengan derajat kebebasan $5 \%$ dan n-2 dengan pengujian dua arah menghasilkan nilai t tabel sebesar 2,048 sehingga artinya t hitung $>\mathrm{t}$ tabel.

Pengujian kriteria penolakan $\mathrm{H}_{0}$ adalah apabila t hitung $>\mathrm{t}$ tabel dan penerimaan $\mathrm{H}_{0}$ adalah $\mathrm{t}$ hitung $<\mathrm{t}$ tabel. Hasil pengujian menjelaskan bahwa t hitung sebesar 5,871> t tabel sebesar 2,048 maka $\mathrm{H}_{0}$ ditolak yang artinya artinya terdapat pengaruh yang signifikan variabel motivasi berprestasi terhadap variabel kinerja guru di SMK Tunas Pemuda.

\section{SIMPULAN}

Peneliti menyimpulkan hasil penelitian adalah sebagai berikut:

1. Hasil pengujian regresi menghasilkan persamaan regresi $\hat{Y}=13,071+0,677 \mathrm{x}$ yang artinya setiap kenaikan satu unit variabel motivasi berprestasi akan meningkatkan variabel kinerja guru sebesar 0,677 dan apabila tidak ada variabel motivasi berprestasi maka kinerja guru akan tetap sebesar 13,071.

2. Hasil pengujian korelasi sederhana menghasilkan nilai 0,743 yang artinya hubungan antara variabel motivasi berprestasi dengan variabel kinerja guru sebesar 0,743 yang artinya hubungan tersebut positif dan kuat. Hubungan yang positif tersebut mengartikan bahwa apabila motivasi berprestasi guru naik maka kinerja guru akan naik dan apabila motivasi berprestasi guru turun maka kinerja guru akan turun. Koefisien determinan menghasilkan nilai 55,2 \% yang artinya motivasi berprestasi menjelaskan kinerja guru sebesar 55,2 \% dan sisanya sebesar 44,8 \% dari variabel lain. 
3. Hasil pengujian menjelaskan bahwa t hitung sebesar $5,871>t$ tabel sebesar 2,048 maka $\mathrm{H}_{0}$ ditolak yang artinya artinya terdapat pengaruh yang signifikan variabel motivasi berprestasi terhadap variabel kinerja guru di SMK Tunas Pemuda.

\section{SARAN}

Peneliti menyarankan untuk pembaca hasil penelitian ini adalah sebagai berikut:

1. Guru harus meningkatkan kinerjanya dalam mengajar di dalam kelas dan membuat Sekolahnya berprestasi.

2. Guru harus meningkatkan motivasi berprestasinya dalam bekerja sehingga mampu untuk meningkatkan kinerjanya.

3. Kepala Sekolah harus membuat pelatihan-pelatihan bagi guru agar guru dapat meningkatkan kinerjanya dan motivasi berprestasinya.

\section{DAFTAR PUSTAKA}

Anwar Prabu Mangkunegara. 2001. Sumber Daya Manusia perusahaan. Remaja. Rosdakarya: Bandung.

Cascio, W.F. 1995. Managing Human Resources : Productivity, Quality of Life, Profits. McGraw-Hill Irwin.

Destiyani, Gati (2012) Pengaruh Motivasi Berprestasi Guru Terhadap Kinerja Guru Sekolah Dasar Negeri di Kecamatan Pringsurat Kabupaten Temanggung. S1 thesis, Universitas Negeri Yogyakarta.

Gagne dan Berliner. 1975. Teori Belajar Behavioristik dan Penerapannya dalam Pembelajaran. Diakses dari laman web http://www.maziatul.com/2009107/teori-belajar-behavioristik-danhtml.

Handoko, T, Hani. 1999, Manajemen, Yogyakarta : BPFE.

Harbani, Pasolong.2010.Kepemimpinan Birokrasi. Bandung : CV.Alfabeta

Heckhausen, H. 1967 . The Anatomy of Achievement Motivation. New York

Lindgren, H.C. 1976. Educational Psychology In The Classroom. New york: John Wiley \& Sons

McClelland, Winter. 1987. Motivating Economic Achievement. New York : Macmillan Company. 
Oemar Hamalik. 2003. Metode Belajar dan Kesulitan-kesulitan Belajar. Bandung: Tarsito.

Rizky, Ahmad S, 2009. Manajemen Pengganjian Karyawan Perusahaan .Jakarta: Gramedia Media Utama.

Santrork, John. 2003. Adolesence Perkembangan Remaja. Jakarta : Erlangga.

Sutikno, M. Sobri, 2007. Belajar dan Pembelajaran: Upaya Kreatif dalam Mewujudkan Pembelajaran yang Berhasil, Bandung: Prospect

Wibowo. 2007. Manajemen Kinerja : Edisi 2. Jakarta : PT. Raja Grafindo Persada. 